\title{
Emergency and Growth of Andiroba Seedlings (Carapa guianensis Aubl.) in Function of the Seeds
}

\author{
Alane Cristina Peixoto de Brito ${ }^{1}$, Antonia Jucineia Braga Sousa ${ }^{1}$, Raimundo Thiago Lima da Silva ${ }^{2}$, \\ Nathalia Sousa Braga ${ }^{1}$, Lucila Elizabeth Fragoso Monfort ${ }^{2}$, Marcos Vinicius Reis de Oliveira Júnior ${ }^{1}$, \\ Wanderson Cunha Pereira ${ }^{2}$, Andressa Pinheiro de Paiva ${ }^{3}$, Vitor Resende do Nascimento ${ }^{3}$ \\ \& Cândido Ferreira de Oliveira Neto ${ }^{2}$ \\ ${ }^{1}$ Federal Rural University of Amazonia, Capitão Poço, Brazil \\ ${ }^{2}$ Federal Rural University of Amazonia, Pará State, Brazil \\ ${ }^{3}$ Federal Rural University of Amazonia, Belém, Brazil \\ Correspondence: Vitor Resende do Nascimento, Federal Rural University of Amazonia, Belém, Brazil. Tel: \\ 55-919-8126-5750. E-mail: vitoresf@gmail.com
}

Received: March 23, 2019

doi:10.5539/jas.v11n9p293
Accepted: April 25, $2019 \quad$ Online Published: June 30, 2019

URL: https://doi.org/10.5539/jas.v11n9p293

The research is financed by Federal Rural University of Amazonia.

\begin{abstract}
Andiroba (Carapa guianensis Aubl.-Meliaceae) is considered an Amazonian forest species with great potential for multiple use in natural forests. Because it is a native species of the Amazon rainforest, it has great socioeconomic importance for the extractive population due to the oil extracted from its seeds. The speed of emergence is an important factor in the establishment of seedlings, since the longer the seeds remain inside the soil, the seeds are in the soil, the greater the chances that the seeds will be attacked by fungi and soil insects. The objective of this work was to determinate the speed of andiroba emergence (Carapa guianensis Aubl.) seedlings and the development. The experiment was carried out in a greenhouse belonging to Federal Rural University of Amazonia (UFRA)-Capitão Poço, Brazil. Fruits of $C$. guianensis were collected in floodplain areas in northeastern of Pará. The treatments were arranged according to the seed mass. Were calculated 5 variables after sowing (emergence speed index; height; interference of the mass of andiroba seeds at the height of the seedlings stem; interference of the mass of andiroba seeds in the number of leaves; interference of the mass of andiroba seeds in the number of leaflets). The experimental design was completely randomized, consisting of 4 treatments with 5 replicates with 5 seeds per replicate ( 5 seeds per vessel), totaling 25 seeds per treatment. The data were statistically analyzed using the Tukey test at $5 \%$ probability with the software Assistat 7.6. The seed mass classes did not influence ESI (Emergence Speed Index). The seed mass promoted significant effects on 4 variables. The mass of the seeds of andiroba does not influence the ESI of seedlings for it own production. The heavy and very heavy seeds generated more developed plants.
\end{abstract}

Keywords: amazon, seedlings, emergence speed index

\section{Introduction}

The Amazon rainforest has as a characteristic the diversity of ecosystems, the lowland forests are examples of these, harboring an ecological and socioeconomic importance for the region (De Abreu et al., 2011). Among the species of the lowland forests are the Andiroba (Carapa spp.), usually common in this forest typology (Coelho de Abreu et al., 2014).

Andiroba (Carapa guianensis Aubl.-Meliaceae) is considered an Amazonian forest species with great potential for multiple use in natural forests, being possible to use it in the production of wood and seeds in a compatible way, depending on the structure forest rates, logging rates and forest type (Klimas et al., 2012). C. guianensis is a perennial tree up to $55 \mathrm{~m}$ in height, with a cylindrical and straight trunk, with a medium crown, dense and composed of upright branches (De Jesus-Barros et al., 2015). Because it is a native species of the Amazon 
rainforest, it has great socioeconomic importance for the extractive population due to the oil extracted from its seeds.

The fruits of the trees of this genus are globose capsules, usually indiscriminate, that release the seeds after opening the fruit during its impact on the ground (De Abreu et al., 2014). Andirobeira seeds have a great deal of differentiation between them, especially with respect to their size, weight and in some cases to their shape. In the same hedgehog, there may be different seeds among them, but well behaved so as to form a kind of spiral.

The seedling emergence test does not only depend on the energy contained in the endosperm or the cotyledons, but also on the physical characteristics of the substrate, such as structure, aeration, water retention capacity and degree of pathogen infestation, as well as temperature, humidity, depth sowing and oxygen availability (Albuquerque et al., 1998; Hackbart \& Cordazzo, 2003; Severino et al., 2004).

The speed of emergence is an important factor in the establishment of seedlings, since the longer the seeds remain inside the soil, the seeds are in the soil, the greater the chances that the seeds will be attacked by fungi and soil insects (Modolo et al., 2011).

There is a very great variability in relation to the weight of the andirobeira seeds, from very light seeds to many heavy seeds in the same fruit, which may be associated among other factors by the non domestication of the species. The same was observed by Carpanezzi et al. (1989) with Euterpe edulis Mart. seeds, which may present variation in weight and size and this variation can be attributed, among other factors, to genetic diversity because it is a non-domesticated species. The classification of seeds by mass is a strategy that can be used to standardize the germination and development of seedlings, obtaining seedlings of similar sizes and/or greater vigor (Carvalho \& Nakagawa, 2012).

There are several studies carried out to verify the influence of seed mass/weight on its germination and on the physiological quality of several plant species. However, in the case of forest, studies are still very scarce, with some species being referred to as jatobá-do-cerrado (Hymenaea stigonocarpa var. stigonocarpa Mart. ex Hayne), ipê-roxo (Tabebuia heptaphylla (Vell.)), tamboril (Enterolobium contortisiliquum (Vell.)), cumaru (Amburana cearenses (Allemão) A.C. Smith) (Lessa et al., 2013; Pereira et al., 2011; Ribeiro et al., 2012; Nobre de Almeida et al., 2014).

Knowledge of factors that affect plant development becomes important to improve nursery techniques. Thus, the objective of this study was to determine the emergence of andiroba seedlings and the vegetative development of the seedlings as a function of seed mass.

\section{Material and Methods}

The experiment was carried out in a greenhouse belonging to the Federal Rural University of the Amazonia, Capitão Poço Campus-Pará, Brazil, March 2016. The andiroba seeds were collected from 35 plants in two municipalities that are located in the northeastern part of the state of Pará: Capitão Poço and Ourém, in areas of farmers in the respective municipalities. These seeds were collected as they fell on the ground, with daily inspection in the area.

After collection, they were screened to separate the healthy seeds from the damaged ones, and then washed in running water.

The treatments were arranged according to the seed mass, so each seed unit was individually weighed on an analytical scale, with an accuracy of $0.0001 \mathrm{~g}$, in order to divide the sample into four distinct classes according to their mass, classified as: light seeds (5.08-11.28 g); intermediate seeds (11.36-13.60 g); heavy seeds (13.61-15.93 g), and very heavy seeds (15.95-25.06 g), which were weighed in the laboratory with the aid of a precision scale. The seeds were placed in trays and then transferred to polyethylene bags with a capacity of $1 \mathrm{~kg}$ of substrate, where in both cases the substrate used was washed white sand and sterilized in the oven at $105^{\circ} \mathrm{C}$. The evaluations were done every two days for the identification of emerged seedlings in order to measure the emergence speed index (ESI).

The Emergency Speed Index (ESI) was determined by recording the number of emerged seedlings in the two-day time period, which was calculated by Equation 1 below proposed by Maguire (1962):

where,

$$
\mathrm{ESI}=\frac{\mathrm{E} 1}{\mathrm{~N} 1}+\frac{\mathrm{E} 2}{\mathrm{~N} 2}+\ldots \frac{\mathrm{En}}{\mathrm{Nn}}
$$

$\mathrm{ESI}=$ emergency speed index; E1, E2, .. En = number of normal seedlings computed at the first count, at the second count and at the last count; $\mathrm{N} 1, \mathrm{~N} 2, \ldots \mathrm{Nn}$ = number of days of sowing to the first, second and last count. 
The seeds stopped emerging in a period of approximately three months, and it was from this period, more specifically 105 days after the implantation of the experiment, that the biometric evaluations of the seedlings were started, which were done biweekly, where the parameters evaluated were: plant height, stem height, number of leaves and number of leaflets. No fertilization was applied during the period.

The parameters listed above were evaluated as follows: the height of the plant was measured with a ruler of 50 $\mathrm{cm}$, from the base of the plant (close to the substrate) to the last leaf. The height of the stem was similarly measured, however, from the base of the plant to the first pair of leaves (leaflet). The count of the leaves and leaflets in turn, were all given manually. The irrigation shift was daily, with amounts of water varying according to the water requirement of the plants.

The experimental design was completely randomized, consisting of 4 treatments with 5 replicates with 5 seeds per replicate, totaling 25 seeds per treatment. The data were statistically analyzed using the Tukey test at $5 \%$ of probability. The computer program used was Assistat version 7.6 (Silva, 2014).

\section{Results and Discussion}

It can be observed in Table 1 that the mass classes of the andirobeira seeds did not statistically influence the emergence speed index (ESI).

Table 1. Emergency speed index of andiroba seedlings, depending on the mass of the seeds

\begin{tabular}{ll}
\hline Treatments & ESI \\
\hline Light seeds & $4.31 \mathrm{a}$ \\
Intermediate seeds & $4.98 \mathrm{a}$ \\
Heavy seeds & $5.90 \mathrm{a}$ \\
Very heavy seeds & $5.62 \mathrm{a}$ \\
\hdashline C.V. $(\%)$ & 27.87 \\
\hline
\end{tabular}

Note. * Means followed by the same letter do not differ by Tukey test at the $5 \%$ probability level.

For seeds of Artocarpus heterophyllus Lam.-Silva et al. (2010) studying the influence of seed size on germination and vigor of seedlings, did not observe significant difference between seed size for emergence percentage.

Such information is fundamental to know the germination potential and use of each source, serving as an indicator of anticipation in obtaining better quality seedlings, as well as to assist in recommending and supporting programs for the recovery of degraded areas, conservation, resources and also to evaluate the genetic variability within populations of the same species (Mendonça et al., 2016; Ken-iti Yokomizo et al., 2016; Bardales-lozano et al., 2016; Silva Moura et al., 2016; Oliveira et al., 2016).

Some seeds were lost in certain treatments, and the main cause was the appearance of the borer caused by a caterpillar (Hypsipyla ferrealis Hampson), the main crop of C. guianensis, which consumes all pulp in the seed, thus embryo and making it inapt to generate a new plant (Pinto, 2013). Factors such as random seed collection, post maturation period and high humidity of the site (floodplain area) may also have contributed to the deterioration of the seeds.

The emergence of the andirobeira seedlings occurred at different periods; there were those that emerged one month after sowing, others after two months, and those that emerged between these two periods, which implied considerable differences in seed sizes, diameters and different physiological factors among them, although they were sowed at the same time.

Bezerra et al. (2002) found that the classification of the seeds of copaiba (Copaifera langsdorffii Desf.) by weight did not affect the percentage, speed and mean germination time, but seedlings from heavy seeds $(0.78$ $\mathrm{g} /$ seed) were more vigorous than the other classes $(0.55,0.63$ and $0.66 \mathrm{~g} / \mathrm{seed})$. Seeds with higher masses are more nourished during their development, being more statistically vigorous due to well formed embryos and with larger amounts of reserves (Carvalho \& Nakagawa, 2012).

It can be seen in Table 2 that seed mass promoted significant effects on seedling initial growth. The seeds of greater mass tend to produce seedlings of higher size, due to the presented results, which point to a constant growth of the seedlings. 
Table 2. Height of andiroba seedlings, according to seed mass, between evaluations from 203 to 245 days after sowing (DAS)

\begin{tabular}{lllll}
\hline Treatments & 203 DAS & 217 DAS & 231 DAS & 245 DAS \\
\hline Light seeds & $27.16421 \mathrm{~b}$ & $28.13978 \mathrm{~b}$ & $28.80921 \mathrm{~b}$ & $30.19667 \mathrm{~b}$ \\
Intermediate seeds & $29.38415 \mathrm{ab}$ & $30.50775 \mathrm{ab}$ & $31.58831 \mathrm{ab}$ & $34.10322 \mathrm{ab}$ \\
Heavy seeds & $31.60278 \mathrm{a}$ & $34.16429 \mathrm{a}$ & $35.12583 \mathrm{a}$ & $39.06944 \mathrm{a}$ \\
Very heavy seeds & $32.72107 \mathrm{a}$ & $35.16972 \mathrm{a}$ & $37.15536 \mathrm{a}$ & $38.45273 \mathrm{a}$ \\
\hline C.V. (\%) & 7.70 & 8.19 & 10.11 & 8.35 \\
\hline
\end{tabular}

Note. ${ }^{*}$ Means followed by the same letter do not differ by Tukey test at the $5 \%$ probability level.

The plants generated from intermediate, heavy and very heavy seeds did not differ statistically in height as a function of time; however, plants from light seeds presented a lower height than the other treatments, except for the intermediates, with the mean being statistically equal to all mass classes analyzed. Table 3 shows the average stem height of the plants in relation to the seed mass classes. Light and intermediate seeds tended to have smaller stems.

Table 3. Interference of the mass of andiroba seeds at the height of the seedlings stem (cm), evaluated from 203 to 231 days after sowing (DAS)

\begin{tabular}{llll}
\hline Treatments & 203 DAS & 217 DAS & 231 DAS \\
\hline Light seeds & $15.92890 \mathrm{~b}$ & $16.23637 \mathrm{~b}$ & $16.28000 \mathrm{~b}$ \\
Intermediate seeds & $17.04727 \mathrm{ab}$ & $17.01296 \mathrm{~b}$ & $17.79125 \mathrm{ab}$ \\
Heavy seeds & $18.65833 \mathrm{a}$ & $18.95714 \mathrm{ab}$ & $19.20087 \mathrm{ab}$ \\
Very heavy seeds & $19.27964 \mathrm{a}$ & $19.95333 \mathrm{a}$ & $20.25231 \mathrm{a}$ \\
\hline C.V. (\%) & 7.70 & 8.96 & 8.78
\end{tabular}

Note. * Means followed by the same letter do not differ by Tukey test at the $5 \%$ probability level.

For the height of the stem, as well as for the height of the plants, the treatment with the light seeds was the one that expressed less height in relation to the others. Starting from the same principle of height of the plant, where the heavier seeds, because they present greater nutritional reserve, end up giving a greater development to the plants, when compared to the seeds of lower weight and nutritional reserve.

Evaluating Table 4, it is possible to observe the average number of leaves of the andirobeira seedlings, the plants originating from light seeds and intermediates presented a smaller number of leaves, except for 217 DAS.

Table 4. Interference of the mass of andiroba seeds in the number of leaves of seedlings evaluated from 203 to 245 days of evaluations after sowing

\begin{tabular}{lllll}
\hline Treatments & 203 DAS & 217 DAS & 231 DAS & 245 DAS \\
\hline Light seeds & $9.46087 \mathrm{~b}$ & $10.10879 \mathrm{a}$ & $10.53365 \mathrm{~b}$ & $11.98064 \mathrm{~b}$ \\
Intermediate seeds & $10.52308 \mathrm{ab}$ & $9.30009 \mathrm{a}$ & $12.58781 \mathrm{ab}$ & $14.06434 \mathrm{ab}$ \\
Heavy seeds & $11.76944 \mathrm{a}$ & $12.99643 \mathrm{a}$ & $13.74722 \mathrm{a}$ & $16.18412 \mathrm{a}$ \\
Very heavy seeds & $10.87766 \mathrm{ab}$ & $12.49500 \mathrm{a}$ & $13.84364 \mathrm{a}$ & $15.10710 \mathrm{a}$ \\
\hline C.V. (\%) & 10.90 & 25.36 & 10.91 & 11.38 \\
\hline
\end{tabular}

Note.* Means followed by the same letter do not differ by Tukey test at the $\%$ probability level.

It is of great importance to identify which seed mass of andirobeira will generate a more developed plant. In view of the development of vital organs of the plant eg leaf. Where the leaf area is directly linked to the photosynthetic rate of the plant, so that certain seeds, for example, may not show good results in this sense. According to Figueiredo Júnior et al. (2005), as photosynthesis depends on the leaf area, the productivity of a crop will be greater the closer it is to the maximum potential leaf area index (LAI) and the longer it remains active, delaying senescence. 
It is observed in table 5 that for all treatments and at all time intervals, the amount of leaflets was ascending due to the vegetative development of the seedlings, the behavior occurred as expected. Seeds of larger masses had more leaflets, except at 203 DAS, where treatments were not statistically different from each other.

Table 5. Interference of the mass of andiroba seeds in the number of leaflets of seedlings evaluated from 203 to 245 days of evaluations after sowing

\begin{tabular}{lllll}
\hline Treatments & 203 DAS & 217 DAS & 231 DAS & 245 DAS \\
\hline Light seeds & $4.63159 \mathrm{a}$ & $4.81275 \mathrm{~b}$ & $5.08190 \mathrm{~b}$ & $5.67968 \mathrm{~b}$ \\
Intermediate seeds & $5.08793 \mathrm{a}$ & $5.48996 \mathrm{ab}$ & $5.93786 \mathrm{ab}$ & $6.58732 \mathrm{ab}$ \\
Heavy seeds & $5.48611 \mathrm{a}$ & $6.02857 \mathrm{a}$ & $6.43198 \mathrm{a}$ & $7.58095 \mathrm{a}$ \\
Very heavy seeds & $5.17366 \mathrm{a}$ & $5.82778 \mathrm{ab}$ & $6.43654 \mathrm{a}$ & $6.97315 \mathrm{ab}$ \\
\hline C.V. (\%) & 12.19 & 11.69 & 11.78 & 11.66 \\
\hline
\end{tabular}

Note. * Means followed by the same letter do not differ by Tukey test at the $5 \%$ probability level.

The treatments of intermediate seeds, heavy and very heavy, were those that expressed better result in the number of leaflets, being equal to each other statistically. However, in numerical terms, the treatment with the highest number of leaflets was that of heavy seeds.

For all treatments, the apex in the number of leaflets was in the period of 245 days after sowing (DAS), which may be associated to the process of continuous vegetative development to which the plant is naturally submitted, causing it to grow in thickness, height, number of leaves and leaflets, among others, depending on the species in question.

\section{Conclusion}

The seed mass of andiroba (C. guianensis Aubl.) does not influence seedling emergence velocity for seedling production. The heavy seeds (13.61-15.93 g) and the very heavy (15.95-25.06 g) generated more developed plants.

\section{References}

Bardales-Lozano, R. M., Edvan, C., Oscar, S., Abanto-Rodriguez, C., Pollyana, C., Adamor, M. F., \& Antonio, C. C. (2016). Genetic divergence among camu-camu plant populations based on the initial characteristics of the plants. Journal of Agricultural Science, 8(11), 51. https://doi.org/10.5539/jas.v8n11p51

Bezerra, A. M. E., Filho, C. B., Moreira, M. G., Moreira, F. J. C., \& Alves, T. T. L. (2002). Germination and development of copaiba seedlings as a function of seed size and immersion in sulfuric acid. Revista Ciência Agronômica, 33(2), 5-12.

Carpanezzi, A. A., Pereira, J. C. D., Carvalho, P. E. R., Reis, A., Vieira, A. R. R., Rotta, E., ... Silveira, R. A. (1989). Ecological zoning for forest plantations in the State of Santa Catarina (Versão de 20/04/89). Colombo: Centro Nacional de Pesquisa de Florestas.

Carvalho, N. M., \& Nakagawa, J. (2012). Seeds: Science, technology and production (5th ed., p. 590). Jaboticabal: FUNEP.

Coelho de Abreu, J., Guedes, M. C., Guedes, A. C. L., \& Batista, E. M. (2014). Structure and spatial distribution of andirobeiras (Carapa spp.) in the Varzea forest of the Amazonian estuary. Ciência Florestal, 24(4). https://doi.org/10.5902/1980509816614

Da Silva Moura, M. L., Edvan, A. C., Oscar, J. S., Rosemary, V., Pollyana, C. C., Elias, A. de M., \& Eliel, E. F. (2016). Biometric characterization, water absorption curve and vigor on araçá-boi seeds. International Journal of Plant Biology, 7(1). https://doi.org/10.4081/pb.2016.6265

De Abreu, J. C., Marangon, J. P., Anjos, R. V., \& Holanda, A. C. (2011). Hypsometric modeling in a lowland forest in the region adjacent to the Amazon River adjacent. Revista Verde de Agroecologia e Desenvolvimento Sustentável, 6(4), 213-218.

De Jesus-Barros, C. R., Lira-Guedes, A. C., Guedes, M. C., Guabiraba-Ribeiro, G., \& Barbosa, E. J. (2015). Record of the occurrence of Hypsipyla ferrealis and Hypsipyla grandella (Lepidoptera: Pyralidae) in fruits of andirobeiras (Carapa guianensis, Meliaceae) in Macapá-AP, Brazil. Ciência Florestal, 25(3), 765-769. https://doi.org/10.5902/1980509819679 
Figueiredo, D. (2005). Basic concepts of remote sensing. Companhia Nacional de Abastecimento-CONAB. Brasília-DF.

Hackbart, V. C. S., \& Cordazzo, C. V. (2003). Seed ecology and establishment of seedlings Hydrocotyle bonariensis Lam.

Ken-Iti Yokomizo, G., Mochiutti, S., Queiroz, J. A. L., Santos, G. R., Furtado, R. G., Brandão, A. P., \& Colares, I. B. (2016). Estimates of genetic parameters for fruit characters in açai trees in amapá. Ciência Florestal, 26(3). https://doi.org/10.5902/1980509824227

Klimas, C. A., Cropper, Jr. W. P., Kainer, K. A., \& Wadt, L. H. de O. (2012). Viability of combined timber and non-timber harvests for one species: A Carapa guianensis case study. Ecological Modelling, 246, 147-156. https://doi.org/10.1016/j.ecolmodel.2012.07.022

Lessa, B. F. T. (2013). Germination and growth of Enterolobium contorsiliquum (Vell.) Morong seedlings as a function of seed weight, fruit location and temperature and light conditions $(60$ f., Dissertação, Mestrado em Agronomia, Universidade Federal do Ceará, Fortaleza).

Maguire, J. D. (1962). Speed of Germination-Aid in Selection and Evaluation for Seedling Emergence and Vigor. Crop Science, 2(2), 176-177. https://doi.org/10.2135/cropsci1962.0011183X000200020033x

Maria, C. de F. A., Terezinha, de J. D. R., Luciane, M., Nilvanira, D. T., \& Lígia, M. de M. S. (1998). Influence of temperature and substrate on seed germination of saguaraji (Colubrina glandulosa Perk.-Rhamnaceae). Revista Brasileira de Sementes, 20(2), 346-349. https://doi.org/10.17801/0101-3122/rbs.v20n2p108-111

Mendonça, A. V. R., Freitas, T. A. S., Souza, L. S., Fonseca, M. D. S., \& Souza, J. S. (2016). Morphology of fruit and seed and germination on Poincianella pyramidalis (Tul.) LP Queiroz, comb. Nov. Ciência Florestal, 26(2), 375-387. https://doi.org/10.5902/1980509822738

Modolo, A. J., Trogello, E., Nunes, A. L., Silveira, J. C., \& Kolling, E. M. (2011). Effect of soil compaction on seed in the development of bean culture. Acta Scientiarum. Agronomy, 33(1).

Nobre de Almeida, J. P., Pinheiro, C. L., Lessa, B. F. T., Gomes, F. M., \& Filho, S. M. (2014). Water stress and seed mass on germination and seedling growth of Amburana cearensis (Allemão) AC Smith. Revista Ciência Agronômica, 45(4). https://doi.org/10.1590/ S1806-66902014000400016

Oliveira, D. L., Paulino, P. P. S., \& Souza, A. D. G. (2016). Water absorption and method improvement concerning electrical conductivity testing of Acacia mangium (Fabaceae) seeds. Revista de Biología Tropical, 64(4), 1651-1660. https://doi.org/10.15517/rbt.v64i4.21944

Pereira, S. R., Giraldelli, G. R., Laura, V. A., \& Souza, A. L. T. (2011). Size of fruits and seeds and their influence on the germination of jatobá-do-cerrado (Hymenaea stigonocarpa var. stigonocarpa Mart. ex Hayne, Leguminosae-Caesalpinoideae). Revista Brasileira de Sementes, 33(1), 141-148. https://doi.org/10.1590/S0101-31222011000100016

Pinto, A. A., Teles, B. R., Anjos, N., \& Couceiro, S. R. M. (2013). Predation of Andiroba seeds [Carapa guianensis Aubl. and Carapa procera DC. (Meliaceae)] by insects in Amazon. Revista Árvore, 37, 1115-1123. https://doi.org/10.1590/ S0100-67622013000600013

Ribeiro, C. A. D., Costa, M. P., Senna, D. S., \& Caliman, J. P. (2012). Factors affecting seed germination and seedling biomass of Tabebuia heptaphylla. Floresta, 42(1), 161-168. https://doi.org/10.5380/rf.v42i1.26312

Severino, L. S., Dionízio, C. G., \& Lucena, A. M. A. (2005). Seedling emergence and germination of castor seed planted in different positions. Revista de Biologia e Ciências da Terra, 5(1).

Silva, F. A. S. (2014). Assistat: statistical assistance (Versão 7.6 Beta). Campina Grande: Universidade Federal de Campina Grande.

Silva, K. S., Mendonça, V., Medeiros, L. F., Freitas, P. S. C., \& Góis, G. B. (2010). Influence of seed size on germination and vigor of jaca (Artocarpus heterophyllus Lam.) seedlings. Revista Verde de Agroecologia e Desenvolvimento Sustentável, 5(4), 217-221.

\section{Copyrights}

Copyright for this article is retained by the author(s), with first publication rights granted to the journal.

This is an open-access article distributed under the terms and conditions of the Creative Commons Attribution license (http://creativecommons.org/licenses/by/4.0/). 